\title{
ANALISA FAKTOR PENYEBAB KREDIT MACET DENGAN METODE QUEST
}

\author{
OLIVIA PRIMA DINI, HAZMIRA YOZZA, DODI DEVIANTO \\ Program Studi Matematika, \\ Fakultas Matematika dan Ilmu Pengetahuan Alam, Universitas Andalas, \\ Kampus UNAND Limau Manis Padang, Indonesia, \\ dini.prima2@gmail.com,hyozza@gmail.com,ddevianto@yahoo.com
}

\begin{abstract}
Abstrak. Perkreditan selalu dibutuhkan bagi pengembangan usaha, yaitu oleh pengusaha yang tengah mengembangkan usaha maupun pengusaha yang baru akan memulai usaha. Dalam suatu proses pemberian kredit, kadangkala terdapat kredit macet yaitu suatu keadaan dimana terjadi tunggakan kredit lebih dari 6 kali masa angsuran. Banyak faktor yang mempengaruhi kredit macet, analisis statistika yang dapat digunakan adalah metode QUEST (Quick, Unbiased, Efficient, Statistical Trees). Pada penelitian ini data yang diambil adalah data nasabah yang mengambil kredit dari tahun 2010 dengan peubah bebas usia, penghasilan, ukuran keluarga, lama kredit, besar cicilan, besar kredit, pekerjaan nasabah, dan jenis kredit. Setelah dilakukan analisa dengan metode QUEST diperoleh faktor yang berpengaruh terhadap kredit macet adalah angsuran dan ukuran keluarga.

Kata Kunci: Kredit Macet, QUEST, Angsuran, Bunga, Jatuh Tempo.
\end{abstract}

\section{Pendahuluan}

Di negara berkembang, perbankan terutama di bidang perkreditan, memiliki peranan yang sangat vital. Perkreditan selalu dibutuhkan bagi pengembangan usaha, yaitu oleh pengusaha yang tengah mengembangkan usaha maupun pengusaha yang baru akan memulai usaha. Dapat dikatakan bahwa kredit memegang peran yang sangat penting bagi suksesnya pembangunan.

Dalam suatu proses pemberian kredit, kadangkala terdapat kredit macet yaitu suatu keadaan dimana terjadi tunggakan kredit lebih dari 6 kali masa angsuran. Ada beberapa faktor yang menyebabkan kredit macet. Beberapa diantaranya adalah usia, penghasilan, ukuran keluarga, lama kredit, besar cicilan, besar kredit, pekerjaan nasabah, dan jenis kredit. Salah satu hal yang menarik, faktor-faktor apa saja yang berpengaruh terhadap macet atau tidaknya kredit tersebut.

Salah satu metode statistika yang dapat digunakan untuk mengetahui faktorfaktor yang berpengaruh terhadap macet atau tidaknya kredit adalah metode QUEST (Quick, Unbiased, Efficient, Statistical Trees). Metode QUEST adalah salah satu bentuk metode pohon klasifikasi yang menghasilkan pohon biner dan bersifat cepat dalam komputasi, menghasilkan pemilihan peubah bebas yang tak bias, serta memiliki algoritma yang efisien.

Penelitian ini bertujuan untuk mengetahui faktor yang mempengaruhi status kredit nasabah dengan menggunakan metode QUEST. Pada penelitian ini, 
faktor-faktor yang diperkirakan mempengaruhi status kredit nasabah adalah usia, penghasilan, ukuran keluarga, lama kredit, besar cicilan, besar kredit, pekerjaan nasabah, dan jenis kredit. Data yang digunakan adalah data nasabah salah satu bank di Kota Padang yang mengambil kredit setelah tahun 2010.

\section{LANDASAN TEORI}

\subsection{Kredit}

Perkreditan selalu dibutuhkan bagi pengembangan usaha, baik oleh pengusaha yang akan mengembangkan usaha maupun pengusaha yang baru akan memulai usahanya. Kredit berasal dari bahasa Yunani "Credere" yang berarti kepercayaan (truth) atau (faith).[1]

Muchdarsyah Sinungan memberikan definisi bahwa: "Kredit adalah suatu pemberian prestasi oleh suatu pihak kepada pihak lain dan prestasi itu akan dikembalikan lagi pada suatu masa tertentu akan datang disertai dengan suatu kontra prestasi berupa bunga".[1]

Dalam prakteknya, tidak semua pengembalian kredit terjadi sebagaimana yang telah disepakati dalam perjanjian.

\subsection{Metode QUEST}

QUEST merupakan metode yang digunakan untuk membentuk pohon klasifikasi. QUEST merupakan algoritma pemisah yang menghasilkan pohon biner yang digunakan untuk klasifikasi. Algoritma pembentukan pohon klasifikasi ini merupakan modifikasi dari analisis diskriminan kuadratik.[4]

Pada algoritma ini, proses penyekatan dapat dilakukan pada peubah tunggal (univariate). Pemilihan peubah penyekat pada QUEST menerapkan uji kebebasan $k h i$-kuadrat untuk peubah kategorik dan uji $F$ untuk peubah numerik. Suatu peubah dipilih sebagai peubah penyekat jika menghasilkan kelompok dengan tingkat kehomogenan peubah respon yang paling besar. Penentuan titik penyekat pada pohon klasifikasi ini dilakukan dengan menerapkan analisis diskriminan kuadratik. Pemilihan peubah dan penentuan titik penyekat dilakukan secara terpisah. Komponen dasar QUEST adalah beberapa peubah bebas yang merupakan peubah kategorik atau numerik dan peubah respon yang merupakan peubah kategorik.

\subsection{Algoritma Pemilihan Peubah Penyekat}

Berikut adalah langkah-langkah pemilihan peubah penyekat:

(1) Untuk setiap peubah bebas $X$ :

- Jika $X$ merupakan peubah kategorik, lakukan uji $\chi^{2}$ untuk kebebasan antara $X$ peubah dan peubah respon $Y$ dan hitung nilai $P$ dari pengujian tersebut.

- Jika $X$ merupakan peubah numerik, lakukan uji ANOVA $F$ dan hitung nilai $P$ dari pengujian tersebut.

(2) Pilih peubah dengan nilai $P$ terkecil. 
(3) Bandingkan nilai $P$ terkecil dengan taraf $\alpha / M_{1}$, pilih taraf nyata $\alpha=0.1$ dengan $M_{1}$ adalah banyaknya peubah bebas.

- Jika nilai $P$ kurang dari $\alpha / M_{1}$, maka pilih peubah yang bersesuaian sebagai peubah penyekat. Teruskan ke langkah (5).

- Jika nilai $P$ lebih dari $\alpha / M_{1}$, teruskan ke langkah (4).

(4) Untuk setiap peubah $X$ yang numerik, maka hitung nilai $P$ dari uji Levene untuk menguji kehomogenan ragam.

- Pilih peubah dengan nilai $P$ terkecil.

- Bandingkan nilai $P$ terkecil dari uji $F$ Levene dengan taraf $\alpha /\left(M_{1}+M_{2}\right)$, dengan $M_{2}$ adalah banyaknya peubah bebas numerik.

- Jika nilai $P$ kurang dari $\alpha /\left(M_{1}+M_{2}\right)$, maka pilih peubah yang bersesuaian sebagai peubah penyekat. Teruskan ke langkah (5).

- Jika nilai $P$ lebih dari $\alpha /\left(M_{1}+M_{2}\right)$, maka peubah tersebut tidak dipilih menjadi peubah penyekat.

(5) Misalkan $X^{*}$ adalah peubah penyekat yang diperoleh dari langkah (3) atau (4).

- Jika $X^{*}$ merupakan peubah numerik, maka teruskan ke langkah (6).

- Jika $X^{*}$ merupakan peubah kategorik, $X^{*}$ ditranformasikan ke dalam peubah dummy, lalu proyeksikan ke dalam koordinat diskriminan terbesarnya.

(6) Lakukan analisis diskriminan kuadratik untuk menentukan titik penyekat.

\subsection{Algoritma Penentuan Titik Penyekat}

Misalkan peubah respon memiliki dua kategori. Misalkan pula bahwa $X^{*}$ merupakan peubah yang terpilih untuk menyekat simpul $t$.

(1) Definisikan $\overline{x_{0}}$ dan $s_{0}^{2}$ adalah nilai tengah dan ragam $X^{*}$ dari pengamatan dengan respon 0 , sedangkan $\overline{x_{1}}$ dan $s_{1}^{2}$ adalah nilai tengah dan ragam $X^{*}$ dari pengamatan dengan respon 1. Misalkan $P(k \mid t)=N_{k, t} / N_{k}$ merupakan peluang dari masing-masing kategori peubah respon, dengan $N_{k, t}$ adalah jumlah data pada simpul $t$ untuk respon $k$ dan $N_{k}$ adalah jumlah data pada simpul awal untuk respon $k$.

(2) Tentukan solusi dari persamaan :

$$
P(0 \mid t) s_{0}^{-1} \varphi\left(\frac{x-\overline{x_{0}}}{s_{0}}\right)=P(1 \mid t) s_{1}^{-1} \varphi\left(\frac{x-\overline{x_{1}}}{s_{1}}\right) .
$$

Solusi tersebut dapat diperoleh dengan menentukan akar persamaan kuadrat

$$
a x^{2}+b x+c=0,
$$

di mana

$$
\begin{aligned}
a & =s_{0}^{2}-s_{1}^{2} \\
b & =2\left(\overline{x_{0}} s_{1}^{2}-\overline{x_{1}} s_{0}^{2}\right), \\
c & =\left(\overline{x_{0}} s_{1}\right)^{2}-\left(\overline{x_{1}} s_{0}\right)^{2}+2 s_{0}^{2} s_{1}^{2} \ln \frac{P(0 \mid t) s_{1}^{2}}{P(1 \mid t) s_{0}^{2}} .
\end{aligned}
$$


(3) Simpul disekat pada titik $X^{*}=d$, di mana $d$ didefinisikan sebagai berikut

(a) Jika $\overline{x_{0}}<\overline{x_{1}}$, maka $d=\overline{x_{0}}$,

(b) Jika $\overline{x_{0}}>\overline{x_{1}}$, maka

- Untuk $a=0$, maka $d=\frac{\overline{x_{0}}+\overline{x_{1}}}{2}-\left(\overline{x_{0}}-\overline{x_{1}}\right)^{2} s_{0}^{2} \ln \frac{P(0 \mid t)}{P(1 \mid t)}$,

- Untuk $a \neq 0$, maka:

- Jika $b^{2}-4 a c<0$, maka $d=\frac{1}{2}\left(\overline{x_{0}}+\overline{x_{1}}\right)$,

- Jika $b^{2}-4 a c \geq 0$, maka $d$ adalah nilai dari $\frac{-b \pm \sqrt{b^{2}-4 a c}}{2 a}$ yang lebih mendekati nilai $\overline{x_{0}}$, dengan syarat menghasilkan dua simpul takkosong.

\subsection{Algoritma Transformasi Peubah Kategorik menjadi Peubah Numerik}

Misalkan $X$ adalah peubah kategorik, dengan kategori $b_{1}, b_{2}, \cdots, b_{L}$. Transformasi $X$ menjadi peubah numerik $\xi$ untuk tiap kelas dilakukan dengan langkah-langkah sebagai berikut.

(1) Transformasikan masing-masing nilai $X$ ke vektor dummy $L$-dimensi $v=$ $\left(v_{1}, v_{2}, \cdots, v_{L}\right)$ dengan $v_{1}=1 \mid x=b_{1}$ dan $v_{1}=0 \mid x \neq b_{1}$.

(2) Cari nilai tengah untuk $X$, yaitu $\bar{v}=\frac{\sum_{l=1}^{L} f_{1} v_{1}}{N_{t}}, \quad v^{-(k)}=\frac{\sum_{l=1}^{L} n_{1} v_{1}}{N_{k, t}}$, dengan

$\bar{v}$ : rata-rata untuk semua pengamatan pada simpul ke $\mathrm{t}$,

$v^{-(k)}$ : rata-rata untuk semua pengamatan pada simpul ke $\mathrm{t}$ untuk kelompok ke $\mathrm{k}$,

$f_{1}$ : jumlah pengamatan pada simpul t untuk $v_{1}$,

$n_{1}$ : jumlah pengamatan pada simpul t kelompok ke-k untuk $v_{1}$,

$N_{t}$ : jumlah pengamatan pada simpul t,

$N_{k, t}$ : jumlah pengamatan pada simpul t untuk kelompok ke-k .

(3) Tentukan matriks $L x L$ berikut

$$
\begin{aligned}
\bar{v} & =\frac{\sum_{l=1}^{L} f_{1} v_{1}}{N_{t}}, \\
v^{-(k)} & =\frac{\sum_{l=1}^{L} n_{1} v_{1}}{N_{k, t}}, \\
B & =\sum_{k=1}^{K} N_{k, t}\left(v^{(k)}-\bar{v}\right)\left(\bar{v}-v^{(k)}\right)^{\prime}, \\
T & =\sum_{k=1}^{K} f_{1}\left(v_{1}-\bar{v}\right)\left(v_{1}-\bar{v}\right)^{\prime} .
\end{aligned}
$$

(4) Lakukan SVD dari $T=Q D Q^{\prime}$, dengan $Q$ adalah matriks orthogonal $L \cdot L$, dengan $d=\operatorname{diag}\left(d_{1}, \cdots, d_{L}\right)$ dengan $d_{1} \geq d_{2} \geq \cdots \geq d_{L} \geq 0$.

(5) Tentukan $D^{-1 / 2}=\operatorname{diag}\left(d_{1} *, \cdots, d_{L} *\right)$, di mana $d_{i} *=d_{i}^{-1 / 2}$ jika $d_{i}>0$.

(6) Lakukan SVD dari $D^{-1 / 2} Q^{\prime} B Q D^{-1 / 2}$, tentukan vektor eigen $a$ yang merupakan vektor eigen yang berpadanan dengan nilai eigen terbesar.

(7) Tentukan koordinat diskriminan terbesar dari $v$, yaitu $\xi=a^{\prime} D^{-1 / 2} Q^{\prime} v$. 


\section{DATA DAN METODE PENELITIAN}

\subsection{Sumber Data}

Data yang digunakan dalam penelitian ini adalah data nasabah salah satu bank di Kota Padang yang melakukan peminjaman pada tahun 2010 - 2012.

\subsection{Peubah}

Peubah yang digunakan dalam penelitian ini terdiri dari peubah tak bebas dan bebas. Peubah tak bebas yang digunakan adalah status kredit nasabah yang terdiri dari 2 kategori, yaitu: nasabah dengan pinjaman yang berstatus macet (M) dan nasabah dengan pinjaman yang berstatus tidak macet (TM). Peubah bebas yang digunakan adalah variabel demografis data nasabah yang terdiri dari komponen demografis, yaitu: Usia $\left(X_{1}\right)$, Jenis Pekerjaan $\left(X_{2}\right)$, Penghasilan keluarga $\left(X_{3}\right)$, Ukuran keluarga $\left(X_{4}\right)$, Lama kredit $\left(X_{5}\right)$,Angsuran $\left(X_{6}\right)$, Jenis kredit $\left(X_{7}\right)$, Besar kredit $\left(X_{8}\right)$.

\subsection{Metode}

Penelitian ini dilakukan dengan tahap-tahap sebagai berikut

(1) Analisa faktor-faktor yang mempengaruhi status kredit dengan menggunakan metode QUEST Langkah-langkah yang dilakukan sebagai berikut

(a) Simpul induk $t_{0}$ adalah simpul yang berisi semua pengamatan

(b) Lakukan pemilihan peubah penyekat dengan cara sebagai berikut

- Untuk peubah $X_{2}$ dan $X_{7}$ yang merupakan peubah kategorik, lakukan uji khi kuadrat untuk kebebasan $Y$ dengan $X$, dengan cara sebagai berikut

i. Bentuk tabel kontingen antara $Y$ dengan $X$

ii. Uji kebebasan antara kedua peubah

Hipotesis:

$H_{0}: X$ dan $Y$ saling bebas

$H_{1}: X$ dan $Y$ tidak saling bebas

Statistik uji yang digunakan adalah $\chi^{2}=\sum_{i=1}^{r} \sum_{j=1}^{c}\left[\frac{\left(O_{i j}-E_{i j}\right)^{2}}{E_{i j}}\right]$ dengan $E_{i j}=n\left(\frac{n_{i .}}{n}\right)\left(\frac{n_{. j}}{n}\right)=\left(\frac{n_{i .} n_{. j}}{n}\right)$

$H_{0}$ ditolak jika nilai dari $\chi^{2}>\chi_{\text {hitung }}^{2}$ dengan $\chi^{2}$ adalah peubah acak $k h i$-kuadrat dengan $d b=(r-1)(c-1)$.

- Untuk peubah numerik $X i$ : (i $=1,3,4,5,6,8)$, lakukan uji kesamaan nilai tengah $X i$ pada kedua status kredit.

Hipotesis:

$$
\begin{aligned}
& H_{0}: \mu_{1}=\mu_{2}, \\
& H_{1}: \mu_{1} \neq \mu_{2} .
\end{aligned}
$$

Statistik uji yang digunakan adalah

$$
F=\frac{s_{1}^{2}}{s_{2}^{2}}, \text { dengan } s_{1}^{2}=\frac{J K K}{K-1} \text { dan } s_{2}^{2}=\frac{J K G}{N-K} .
$$


Jika $F_{\text {hitung }}>F_{\alpha, 1, n-2}$, maka tolak $H_{0}$, yang berarti bahwa peubah memiliki nilai tengah yang tidak sama, sehingga mempengaruhi status kredit. Sebaliknya, jika $F_{\text {hitung }}<F_{\alpha, 1, n-2}$, maka tidak tolak $H_{0}$, yang berarti peubah memiliki nilai tengah yang sama sehingga tidak mempengaruhi status kredit.

(2) Pilih $P$-value terkecil dan bandingkan dengan $\alpha / M_{1}$.

- Untuk $P$-value yang kecil dari $\alpha / M_{1}$ pilih peubah tersebut sebagai peubah penyekat.

- Untuk $P$-value yang besar dari $\alpha / M_{1}$ lakukan uji $F$-levene.

(3) Pilih titik penyekat.

(4) Sekat simpul menjadi dua anak simpul $t_{1}$ dan $t_{2}$.

(5) Ulangi langkah 1 dan 2 untuk simpul dua anak.

\section{HASIL DAN PEMBAHASAN}

\subsection{Uji Hipotesis Kebebasan Peubah-peubah Kategorik dengan Status Kredit}

Untuk menguji hipotesis kebebasan peubah ketegorik ada beberapa tahapantahapan yang harus di lakukan. Sebagai ilustrasi akan diperlihatkan pengujian kebebasan peubah jenis kredit dan status kredit. Hipotesis yang diuji adalah

$$
\begin{aligned}
& H_{0}: X \text { dan } Y \text { saling bebas. } \\
& H_{1}: X \text { dan } Y \text { tidak saling bebas. }
\end{aligned}
$$

Statistik uji yang digunakan adalah

$$
\chi^{2}=\sum_{i=1}^{r} \sum_{j=1}^{c}\left[\frac{\left(O_{i j}-E_{i j}\right)^{2}}{E_{i j}}\right] \text {, dengan } E_{i j}=n\left(\frac{n_{i .}}{n}\right)\left(\frac{n_{\cdot j}}{n}\right)=\left(\frac{n_{i .} n_{\cdot j}}{n}\right) .
$$

Nilai statistik uji dapat dihitung dengan menggunakan tabel kontingensi sebagai berikut.

Tabel 4.2.1 Tabel Kontingensi Antara Jenis Kredit Dengan Status Kredit

\begin{tabular}{|l|l|l|l|}
\hline \multirow{2}{*}{ Status kredit } & Jenis Kredit & Jumlah \\
\cline { 2 - 3 } & Produktif & Konsumtif & \\
\hline Macet & 145 & 24 & 169 \\
\hline Tidak Macet & 260 & 34 & 294 \\
\hline Jumlah & 405 & 58 & 463 \\
\hline
\end{tabular}

Jika persamaan tersebut disubsitusikan ke dalam jenis kredit maka diperoleh $\chi^{2}=0,68078$. Hitung $P$-value dari pengujian, yaitu nilai dari $P\left(\chi^{2}>\chi_{\text {hitung }}^{2}\right)$ dari setiap sebaran dengan $d b=(r-1)(c-1)$.

$$
P \text {-value }=P\left(\chi_{1}^{2}>0,68078\right)=0,656079
$$

Dapat dilihat bahwa : 0,656079 $>0,05$ sehingga $P>\alpha$. Hal ini berarti $H_{0}$ diterima. Dapat disimpulkan bahwa antara jenis kredit dan status kredit saling bebas. Akibatnya, jenis kredit tidak berpengaruh terhadap status kredit. 
Dengan cara yang sama pada uji hipotesis jenis pekerjaan dengan status kredit diperoleh nilai hitung $=5,836$ dan $P$-value $=0,119868$. Karena 0,119868 $>$ 0, 05, maka haruslah $P>\alpha$. Hal ini berarti $H_{0}$ diterima. Dapat disimpulkan bahwa antara jenis pekerjaan dan status kredit saling bebas. Akibatnya, jenis pekerjaan tidak berpengaruh terhadap status kredit.

\subsection{Hipotesis Kesamaan Nilai Tengah Peubah Numerik}

Untuk menguji hipotesis kesamaan nilai tengah peubah numerik ada beberapa tahapan-tahapan yang harus di lakukan. Untuk mengilustrasikan tahapan-tahapan tersebut, dipilih peubah lama kredit untuk dilakukan uji hipotesis kesamaan nilai tengah. Untuk menguji kesamaan nilai tengah hipotesis yang digunakan adalah sebagai berikut

$$
\begin{aligned}
& H_{0}: \mu_{1}=\mu_{2} \\
& H_{0}: \mu_{1} \neq \mu_{2}
\end{aligned}
$$

Selanjutnya dibentuk tabel $A N O V A$ agar kita dapat menentukan nilai $F_{\text {hitung }}$.

Tabel 4.3.1
Tabel ANOVA Lama Kredit Berdasarkan Status Kredit
\begin{tabular}{|l|l|l|l|l|}
\hline Sumber Keragaman & Jumlah & Derajat Bebas & Kuadrat Tengah & $F_{\text {Fitung }}$ \\
\hline Nilai Tengah Kolom & 17,09348 & 1 & 17,09348 & 0,22 \\
\hline Galat & 35818,61 & 461 & 77,69764 & \\
\hline Total & 35896,31 & 462 & & \\
\hline
\end{tabular}

Dari tabel tersebut diperoleh $F_{\text {hit }}=0,22$. Karena $F_{\text {hit }}<F_{\text {tabel }}$, maka tolak $H_{0}$ yang berarti bahwa nilai tengah lama kredit berbeda untuk kedua status kredit atau dengan kata lain lama kredit tidak berepengaruh terhadap status kredit.

Dengan menggunakan Minitab diperoleh hasil pengujian untuk peubah-peubah lain sebagai berikut. Kemudian kita bandingkan $P$ dengan $\alpha$ untuk membuat kesim-

\begin{tabular}{|l|l|l|}
\multicolumn{3}{|c|}{ Tabel 4.3.2 Tabel Hasil uji $F$} \\
\hline Pseubah & Nilai uji & Nilai $P$-value \\
\hline Penghasilan & 2,18 & 0,141000 \\
\hline Ukuran keluarga & 5,08 & 0,025000 \\
\hline Lama kredit & 4,34 & 0,038000 \\
\hline Angsuran & 0,22 & 0,640000 \\
\hline Besar kredit & 4,37 & 0,037000 \\
\hline
\end{tabular}

pulan. Dari Tabel 4.3.2 dengan mengambil $\alpha=0,05$, akan dibandingkan $P$ dengan $\alpha$. Setelah $P$ dengan $\alpha$ dibandingkan, dibuat kesimpulan dengan kriteria sebagai berikut

- Untuk $P>\alpha$ tidak tolak $H_{0}$ (peubah tidak berpengaruh terhadap status kredit) 
- Untuk $P>\alpha$ tolak $H_{0}$ (peubah berpengaruh terhadap status kredit)

Dengan menggunakan hasil Tabel 4.3.2 dapat dilihat bahwa yang mempengaruhi status kredit adalah penghasilan,ukuran keluarga,angsuran dan besar kredit.

\subsection{Pohon klasifikasi}

Dengan menggunakan metode QUEST, didapatkan pohon klasifikasi sebagai berikut

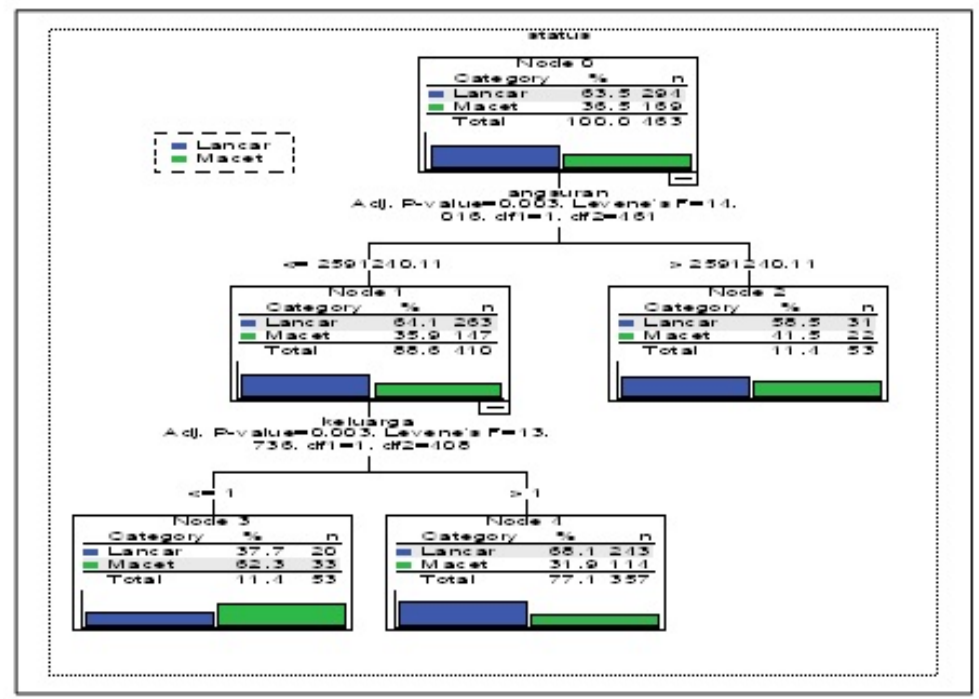

Gambar 4.1. Pohon Klasifikasi

Pada tahap awal penyekatan, simpul induk yang terdiri dari 461 nasabah disekat berdasarkan peubah berdasarkan angsuran menjadi dua anak simpul, yaitu simpul 1 dan 2. Simpul 1 adalah simpul yang berisikan 410 orang nasabah dengan besar angsuran kurang atau sama dengan Rp.2.591.240,11,--, sedangkan simpul 2 adalah simpul untuk 53 orang nasabah dengan besar angsuran lebih dari Rp.2.591.240,11,-. Proses selanjutnya, simpul 2 tidak disekat lebih lanjut sementara simpul 1 disekat menjadi dua anak simpul berdasarkan ukuran keluarga. Nasabah dengan ukuran keluarga yang sama dengan 1 masuk ke simpul 3 dan nasabah dengan ukuran keluarga lebih dari 1 merupakan simpul 4. Terdapat 53 nasabah pada simpul 3 dan 357 nasabah pada simpul 4. Pada proses selanjutnya, penyekatan terhadap kedua simpul baru ini dihentikan.

Dari proses yang telah dijelaskan tersebut, dapat diketahui hanya dua peubah yang berpengaruh terhadap kelancaran pembayaran angsuran kredit dari nasabah bank A. Kedua peubah tersebut adalah besarnya angsuran dan jumlah anggota keluarga. Dengan demikian, dapat dijelaskan karakteristik tiga simpul akhir yang terbentuk. 
(1) Kelas pertama yaitu nasabah dengan angsuran lebih dari Rp.2.591.240,11,-Nasabah dengan karakteristik ini diduga tidak mengalami kredit macet.

(2) Kelas kedua yaitu nasabah dengan angsuran kurang dari Rp.2.591.240,11,- dan jumlah anggota keluarganya 1 . Nasabah pada kelompok ini diduga akan mengalami kredit macet.

(3) Kelas ketiga yaitu nasabah dengan angsuran kurang dari Rp.2.591.240,11,- dan jumlah anggota keluarganya lebih dari 1 . Nasabah pada kelompok ini diduga tidak mengalami kredit macet.

Dengan dugaan klasifikasi tersebut, akan disusun pengklasifikasian sebagai berikut.

Tabel 4.4.1 Tabel Klasifikasi

\begin{tabular}{|l|l|l|}
\hline \multirow{2}{*}{ Status } & \multicolumn{2}{|l|}{ Dugaan } \\
\cline { 2 - 3 } & Tidak Macet & Macet \\
\hline Tidak Macet & 274 & 136 \\
\hline Macet & 20 & 33 \\
\hline
\end{tabular}

Dari tabel tersebut dapat diketahui bahwa dari 294 nasabah yang kreditnya tidak macet, 274 akan diklasifikasikan secara benar ke dalam kelompok dengan kredit tidak macet, sementara 20 orang lainnya diklasifikasikan ke dalam kelompok dengan kredit macet. Dan dari 169 nasabah yang kreditnya macet, hanya 33 orang yang diklasifikasikan secara benar, sedangkan 136 nasabah lainnya diklasifikasikan secara salah ke dalam kelompok dengan kredit tidak macet. Dari uraian tersebut terdapat kesalahan klasifikasi sebesar $\frac{20+136}{463}=0,336933$. Sehingga, kesalahan klasifikasinya adalah sebesar 33.69.

\section{Penutup}

\subsection{Kesimpulan}

Setelah dilakukan pengklasifikasian dengan menggunakan metode QUEST faktor yang menyebabkan kredit macet adalah angsuran dan ukuran keluarga.

\subsection{Saran}

Pada kesempatan ini, penerapan metode QUEST dilakukan untuk kasus kredit macet. Metode ini dapat digunakan untuk kasus-kasus lainnya. Selain itu Metode ini dapat dilanjutkan dengan penambahan lebih banyak lagi peubah bebas sehingga hasil yang di dapatkan lebih baik.

\section{Daftar Pustaka}

[1] Anonim. 2003. Penyelesaian Kredit Macet. Universitas Sumatera Utara. Medan. 
Analisa Faktor Penyebab Kredit Macet dengan Metode QUEST 85

[2] Faridhan, Y.E. 2003. Metode Klasifikasi Berstruktur Pohon Dengan Algoritma CRUISE, QUEST, dan CHAID.

[3] Loh W-Y, Shih Y-S. 1997. Split Selection Methods for Classfication Trees. Stastistica Sinicar; 815-840.

[4] Martono, N. 2010. Statistik Sosial Teori dan Aplikasi Program SPSS. Gava Media: Yogyakarta.

[5] Pratiwi, Niken. 2008. Analisis Perbandingan Pohon Klasifikasi antara Metode Quest dengan Metode chaid. Institut Pertanian Bogor. Bogor. 